\title{
Elevación de seno maxilar. Análisis clínico de nuestra experiencia en más de 100 casos
}

\author{
Clinical analysis of our experience in over 100 cases of maxillary sinus lift
}

El presente trabajo nos muestra la experiencia de un Servicio hospitalario de Cirugía Oral y Maxilofacial en los injertos óseos del seno maxilar a lo largo de 12 años con unos resultados excelentes. Aunque se trata de un estudio retrospectivo y con una distribución asimétrica de las variables, analiza de forma exhaustiva y científicamente válida los resultados obtenidos.

Los autores presentan una gran serie de injertos óseos sinusales realizados en un único centro hospitalario, aunque la muestra puede resultar muy heterogénea al estar realizados a lo largo de muchos años (durante los cuales la técnica ha ido evolucionando y cambiando progresivamente) y no especificar si fueron realizadas por uno o varios cirujanos. La tasa de éxito de los implantes $(96,91 \%)$ es sin duda más alta que en series similares descritas en la literatura.

El término "elevación del seno maxilar" debería sustituirse por "injerto óseo del seno maxilar". El primero proviene de la traducción literal del término inglés "sinus lift" y hace referencia al despegamiento y elevación de la membrana de Schneider que no deja de ser el primer paso para poder realizar un injerto óseo sinusal. Sólo sería correcto emplear este término si no realizásemos el injerto de ningún material adicional. Si injertásemos algún material de origen "no óseo" sería correcto hablar de "injerto sinusal" y si, como ocurre en la mayoría de los casos, se injerta material óseo de una u otra naturaleza creo que debemos emplear el término "injerto óseo sinusal".

Llama la atención que en todos los pacientes el control radiológico pre y postoperatorio se realizó mediante ortopantomografía (OPT) y tomografía computerizada (TC) dental. En la pasada Conferencia de Consenso sobre Injerto Óseo del Seno maxilar de Oviedo (resultados pendientes de publicar) se estableció la conveniencia de realizar un estudio preoperatorio mediante TC (además de OPT) con el fin de analizar la existencia de patología sinusal previa y de malformaciones o anomalías anatómicas que pudieran dificultarnos la realización del injerto. La necesidad de realizar una TC postoperatoria sólo estaría justificada en caso de implantes diferidos, para valorar el hueso disponible. Sin duda, el ámbito hospitalario donde se realizó este trabajo ha permitido a sus autores realizar estudios radiológicos tan precisos, obviando entre otras cosas su coste económico y la cantidad de radiación recibida por los pacientes.

Por esta misma razón, sorprende que el $76,2 \%$ de los casos se realizaron bajo anestesia general. Sin duda, la técnica se puede realizar bajo anestesia local en la mayoría de los casos, siendo sólo necesaria la anestesia general cuando obtenemos injertos de áreas
This work shows us the experience that that a Service Hospital of Oral and Maxillofacial Surgery of bone grafts of maxillary sinus over 12 years with excellent results. Although it is a retrospective study and with an asymmetrical distribution of variables, it exhaustively analyzes and scientifically validates the results obtained.

The authors present a large series of sinus bone grafts carried out in one hospital, although the sample could be heterogeneous because the operations were carried out over many years (during which time the technique had progressed and changed progressively) and the study doesn't specify if the operations were carried out by the same surgeon or by various surgeons. The implant success rate (96.91\%) is without a doubt the highest of any series in the literature.

The term "Maxillary sinus lift" should be replaced by "bone graft of the Maxillary sinus". The first term is literally translated from English "Sinus lift" and refers to the detachment and elevation of the Schneider membrane which is the first step when carrying out a sinus bone graft. It would only be correct to use this term if we didn't perform the graft with any additional material. If we graft any material that is of "non bone" origin, it would be correct to talk about sinus graft and yes, as in the majority of cases, the bone graft material from one nature or another should be referred to as sinus bone graft.

It is shocking that all of the patients had radiological control before and after surgery using a orthopantomograph and dental CT. At the past Board Conference about Bone grafts of the Maxillary Sinus in Oviedo they established the convenience of carrying out a preoperative study using $C T$ (aside from the OPT) in an attempt to analyze the existence of a previous sinus pathology and anatomic deformities or irregularities that could make grafting difficult. The necessity to have a post operative CT would only be justified in the cases where implants were delayed to evaluate the bone available. Without a doubt, the hospital environment where these jobs were performed has allowed its authors to carry out such precise studies, circumventing, among other things the economic cost and the quantity of radiation that the patients received.

Due to this, it is surprising that $76.2 \%$ of the cases were carried out under general anesthesia. Without a doubt, this technique can be performed using a local anesthetic in the majority of the cases. General anesthetic is only necessary 
donantes extraorales como la cresta iliaca o la calota, actos prescindibles salvo que realizamos injertos de aposición simultáneos.

Los autores indican la batería de instrumentos que utilizaron para realizar la antrostomía lateral sin decantarse por ninguno en especial y sin especificar cuándo utilizaron cada uno y en base a qué criterios. Probablemente, esto esté motivado por el análisis de casos tan distanciados en el tiempo. Tampoco nos indican si los casos de perforación de la membrana se produjeron al usar unos determinados instrumentos y si los casos de sinusitis estuvieron relacionados con perforaciones de la membrana, sin duda hechos relevantes a la hora de sacar conclusiones.

En el trabajo se describen la variedad de tipos de injertos óseos utilizados a lo largo del largo tiempo de estudio, sin indicar las razones o los criterios en base a los cuales fueron empleados. Puede deducirse que usaron derivados bovinos más hueso autólogo en los casos que no precisaron injertos de aposición, e injertos de cresta ilíaca o calota en los que si los necesitaron. En muchos casos debía existir una gran atrofia ósea transversal que se refleja por el alto porcentaje de pacientes en los que se asociaron injertos óseos de aposición (41\%), lo cual se asemeja con la cifra de los casos en los que se emplearon injertos de la cresta iliaca y calota (35\%). Su forma de actuar concuerda con la opinión más generalizada actualmente: la primera indicación para un injerto óseo sinusal sin injertos de aposición son los xenoinjertos junto con pequeñas cantidades de hueso autólogo obtenido mediante raspadores óseos. En los casos donde se necesitan injertos de aposición podremos utilizar zonas donantes intraorales (rama o sínfisis mandibular) si no necesitamos incrementar mucho la anchura de la cresta ósea o injertos de cresta ilíaca o calota si la atrofia ósea transversal es extrema.

La colocación de los implantes se realizó de manera simultánea $(64,7 \%)$ cuando la altura ósea inicial fue de al menos $5 \mathrm{~mm}$, consiguiendo, al actuar de forma tan prudente, una estabilidad adecuada que posiblemente es la que justifica sus magníficos resultados. Sin duda, la tasa de éxito implantario depende más de la estabilidad primaria del implante que del tipo de injerto empleado. A la hora de colocar implantes simultáneos, aparte de valorar la altura ósea preoperatoria del reborde alveolar es fundamental valorar también la densidad y la calidad del hueso crestal residual. Esto se puede valorar fundamentalmente si disponemos de estudios tomográficos preoperatorios, como en el presente trabajo. Si además disponemos de TC postoperatorias es una pena no haber estudiado la calidad del hueso neoformado y la reabsorción periimplantaria crestal y apical a lo largo del tiempo de estudio. Posiblemente en estos dos parámetros si hubiesen obtenidos peores resultados en los pacientes fumadores.

El mayor éxito (estadísticamente significativo) en cuanto a supervivencia de los implantes colocados de forma inmediata respecto a los diferidos parece anecdótico y de escaso valor clínico según los autores. Sin embargo, estos resultados animan a seguir colocándolos de esta forma siempre y cuando la estabilidad primaria sea suficiente, pues las ventajas son múltiples y claras (menor tiempo de espera y menos intervenciones quirúrgicas).

En este artículo no se especifica ningún criterio que sirviese para decidir el momento de colocar los implantes diferidos y car- when the grafts are being taken from extra oral locations like the iliac crest or the calvarium, necessary acts except when apposition grafts are carried out simultaneously.

The authors indicate the collection of instruments that are used to carry out the lateral anthrostomy without emptying for anything special or specifying when each one is used and under what circumstances. This is probably because these cases were performed such a long time ago. This article also does not specify if the cases of membrane tear were caused by the use of specific instruments or if sinusitis cases were related to membrane tears. It is obvious that this information is relevant when drawing conclusions about the data.

The article describes the different types of grafts used throughout the long period of the study; however it does not mention the reasons or criteria used when deciding which graft to use. We can conclude hat they used bovine derivative and autologous bone in cases where apposition grafts were not needed and iliac crest or calvarium grafts when an apposition graft was needed. There should have been a lot of transversal bone atrophy in many of the cases that reflects the high percentage of patients that had apposition bone grafts (41\%) this conforms to the amount of cases that iliac crest and calvarium grafts were used (35\%). Its behavior coincides with the current general opinion: the first indication of a sinus bone graft without apposition grafts are xenografts and small quantities of autologous bone retrieved using bone scrapers. In cases where apposition grafts were needed we could use intraoral donor zones (ramus or mandible symphysis) if we don't need to increase the width of the bone crest or if the transversal bone atrophy is extreme, calvarium or iliac bone grafts.

Placement of the implants was done simultaneously (64.7\%) when the initial bone height was at least $5 \mathrm{~mm}$, subtly achieving stability that could justify the magnificent results. Without a doubt the implant success rate depends more on primary implant stability than the type of implant used. When placing implants simultaneously, aside from the importance of the preoperative alveolar ridge height, the density and quality of the residual crest bone is very important. This can be evaluated if preoperative tomography is taken, like it was in this project. If we also make post operative CT's available it is a shame not to have studied the neoformed bone quality, the crestal and lingual peri-implant resorption. If in addition to this we take post operative $C T$, it is a shame that the neoformed bone quality was not studied and the peri-implantary and lingual resorption through out the study. If these data were studied perhaps the results would have been worse for smokers.

The greatest success rate (statistically significant) in terms of the immediate survival of placed implants seemed to be, according to the authors unimportant and clinically undervalued. However, these results encourage us to continue placing them in this way whenever the primary stability is sufficient. The advantages are numerous and clear(less wait time and less surgical interventions). 
gar la prótesis. Las diferencias encontradas en cuanto al tiempo de espera para colocar diferidamente los implantes y cargarlos no tiene ningún valor real, porque esto, entiendo, se realizó en función de la experiencia de los cirujanos y lo descrito y recomendado en la literatura científica (menor tiempo en caso de usar hueso autólogo). No podemos concluir, por los resultados obtenidos en este estudio, que al emplear injertos autólogos se requiera un tiempo de espera menor para la colocación de los implantes o la carga protésica. Nos falta para ello un parámetro clínico que nos indique el estado de maduración ósea; esto sólo puede intuirse mediante estudios de TC y comprobarse mediante un estudio histológico.

Debemos felicitar a los Autores por su trabajo y sus excelentes resultados, animándoles a seguir investigando, desde su situación privilegiada de trabajar en un medio hospitalario, sobre las ventajas e inconvenientes de los nuevos materiales de injerto óseo Invitarles también a profundizar en las nuevas técnicas de cultivos celulares e ingeniería tisular y en las incógnitas que todavía nos asaltan como son la maduración ósea que se produce con cada biomaterial, las causas de las complicaciones y el momento más adecuado para colocar los implantes y cargarlos.

\section{Pedro Villarreal Renedo \\ FEA del Servicio de Cirugía Oral y Maxilofacial. Hospital Universitario Central de Asturias. Práctica privada. Oviedo, España. \\ Lorena Gallego López MIR del Servicio de Cirugía Oral y Maxilofacial. Hospital Universitario Central de Asturias. Oviedo, España.}

This article does not specify any criteria that helps decide when to place delayed implants or set the prosthesis. The differences we found in terms of wait time for delayed implants and setting doesn't have any real value. Because of this reason I understand, it was carried out according to both, the experience of the surgeons and what is written and recommended in the scientific literature(less time when using autologous bone) We can not conclude because of the results we obtained in this study, that when using autologous bone grafts less waiting time is needed for implant placement or prosthetic setting. We are missing a clinical parameter that indicates the state of bone maturity; this can only be measured using CT studies and checked using a histological study.

We should congratulate the authors for their work and excellent results, encouraging them to continue to investigate from their privileged position at their hospital, about the advantages and inconveniences of the new bone graft materials. We also invite them to go deep inside the new cell cultivating and tissue engineering techniques and in the unknown: like bone maturation that is produced with each biomaterial; the causes of complications and the most importantly the right moment to place and load implants.

\section{Bibliografía}

1. Hage G. Crestal sinus floor elevation. En: Khoury F, Antoun H, Missica P ed. Bone augmentation in oral implantology. Berlin, Quintessence Publishing Co, Ltd. 2007:321-39.

2. Achong RM, Block MS. Sinus floor augmentation: simultaneous versus delayed implant placement. En: Jensen OT ed. The Sinus bone graft. $2^{\circ}$ ed. London, Quintessence Publishing Co, Ltd. 2006.

3. Use of xenograt for sinus augmentation. Froum SJ, Wallace SS, Cho S, Tarnow D. En: Jensen OT ed. The Sinus bone graft. $2^{\circ}$ ed. London, Quintessence Publishing Co, Ltd. 2006. 